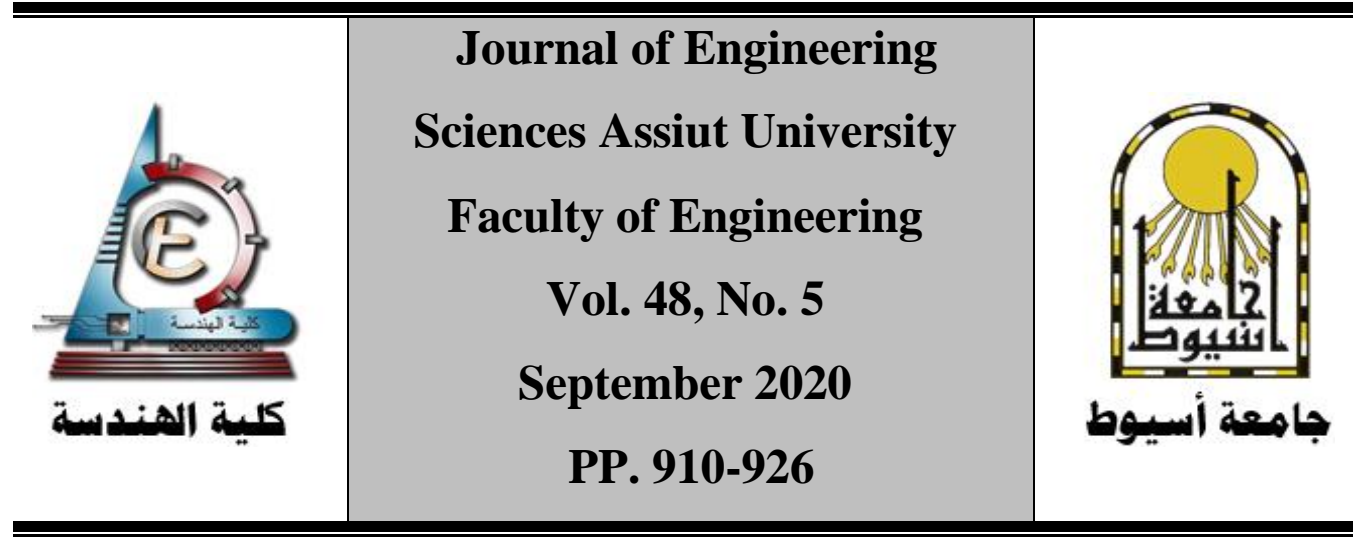

\title{
SPACE SYNTAX AS AN EVALUATIVE AND PREDICTIVE TOOL TO EXPLORE URBANITY LEVELS IN NEW DAMIETTA CITY
}

\author{
Asmaa Eldiasty ${ }^{1}$, Medhat Samra ${ }^{2}$, Alaa Eleishi ${ }^{3}$ \\ ${ }^{1}$ Master candidate, Department of Architecture, Faculty of Engineering, Mansoura \\ University, Egypt.E-mail: asmaa_eldiasty@yahoo.com (Corresponding Author) \\ ${ }^{2}$ Lecturer, Department of Architecture, Faculty of Engineering, Mansoura \\ University, Egypt. E-mail: medhatsat2005@hotmail.com \\ ${ }^{3}$ Assoc. Prof., Department of Architecture, Faculty of Engineering, Mansoura \\ University, Egypt.E-mail: arabeskal_arch@yahoo.com
}

Received 15 April 2020; Revised 14 May 2020; Accepted 31 May 2020

\begin{abstract}
In New Damietta city, many residential neighborhoods have the appearance of empty, dull, and monotonous places. These neighborhoods have low levels of urbanity in terms of vital and flourishing street life. Some researchers attribute the low levels of urbanity in new cities to the urban planning approaches undertaken (the neighborhood unit). To conduct this research, we used space syntax analysis as a key method to study urbanity in New Damietta city. In addition to other methods such as direct field observations through which we observed land use patterns and activities occurred in the study area. Observed land use patterns and activities were mapped in Geographical Information System (GIS). This study finds out how space syntax is an effective tool that can evaluate the current situation of urbanity and how it can be used as a predictive tool in the planning processes in the forthcoming generations of new cities.
\end{abstract}

KEYWORDS: Space syntax, Depth map, Observations, New cities in Egypt, Urbanity 


\section{Introduction}

New Damietta city was planned according to the neighborhood unit model [1]. This model aims at creating social cohesion, decrease segregation, and increase interactions among inhabitants in the city spaces [2]. Perry assumed that the facilities in the neighborhoods' centers would bring inhabitants together in face-to-face encounters, then friendly relations and social activities would be created among them. However, many new cities planned according to the neighborhood unit model suffer low levels of urbanity based on observations. The term urbanity we are searching in this paper refers to social and economic activities and interactions among people in the city spaces. In New Damietta city many residential neighborhoods seem dull and empty during a long period of the day, even in some areas with high population density and diversity of land uses.

Some researchers found that the lack of vibrant street life in some residential neighborhoods is due to the planning approaches undertaken [3- 4]. They criticized the neighborhood unit model as it was found that it enhances segregation rather than cohesion in the city. Some social researchers asserted that the model was based on the separation of land uses, population classes, and segregation of vehicular and pedestrian flow [5]. They argued that this model is no longer suitable for contemporary human needs. The low level of urbanity influences the social, economic, and urban growth of the city and makes it not preferable for some people to inhabit. According to the national censuses $(1986,1996,2006,2016)$, there is a huge gap between the actual (around 5.8\%) and supposed growth rates (95\%) for new cities, many of them are still far away from the target population supposed by the government [6]. In the case of new Damietta city, the challenges are lack of flourishing street life inside the neighborhoods, low street network integration and poor land use distribution. Space syntax analysis was used by many researchers to analyze and understand the configurational structure in new cities. It was used to analyze the street network of new cities in England [4], new cities in China [7], and new cities in The Netherlands [8].

In this paper, we used space syntax analysis as a key method to understand the relationship between urban spaces and inhabitants and how the spatial configuration of the city can influence social and economic activities through its spaces. In addition, we used observations and activity mapping to reveal patterns of interactions in the city spaces. The aim of this study is to find the importance of spatial analysis (space syntax) in investigating urbanity levels in new cities and find to what extent these methods can be used during the planning phases to predict how new cities will perform. It will help urban planners and researchers enhance levels of urbanity in new cities. 


\section{Selection of case study}

New Damietta city was selected for the study due to its importance as a coastal city and its location near to Old Damietta city. The city is located along the Mediterranean Sea with a length of $9 \mathrm{~km}$ and it is $4.5 \mathrm{Km}$ far from Damietta Port. The total area of the city is 6500 acres. It consists of residential settlements, downtown, coastal area (length of $5 \mathrm{~km}$ ), the smart village, the Olympic Village, university, International Park, industrial area, and Cemeteries area [1]. The city was established with the aim of limiting the growth of Old Damietta city and its expansion on the agricultural land, providing services needed by Damietta Governorate, which did not exist before such as university and industrial areas, and developing tourism sector [1]. To conduct this research, we selected an area located in the $2^{\text {nd }}$ and $3^{\text {rd }}$ neighborhoods. The selected neighborhoods have a high population, and its center has a diversity of land uses figure (1). The problems of New Damietta city are the low degree of the street network configuration inside the residential neighborhoods and poor land use mix that affected urbanity levels in the city. Some areas with a diversity of land uses are not accessible due to the low integration degrees of the street network. The hypothesis of the study is that using spatial analysis techniques to evaluate street network configuration will help improve the urbanity level of the city.

\subsection{Urbanity making}

Urban vitality, urban quality, and urban life all have the same meaning as urbanity. Urban vitality expresses the interactions between the built environment and its inhabitants; daily activities that people are engaged in, celebrations and cultural events across the year [9]. In this research, urbanity is concerned with social and economic activities and interactions between people in city spaces through their everyday life.

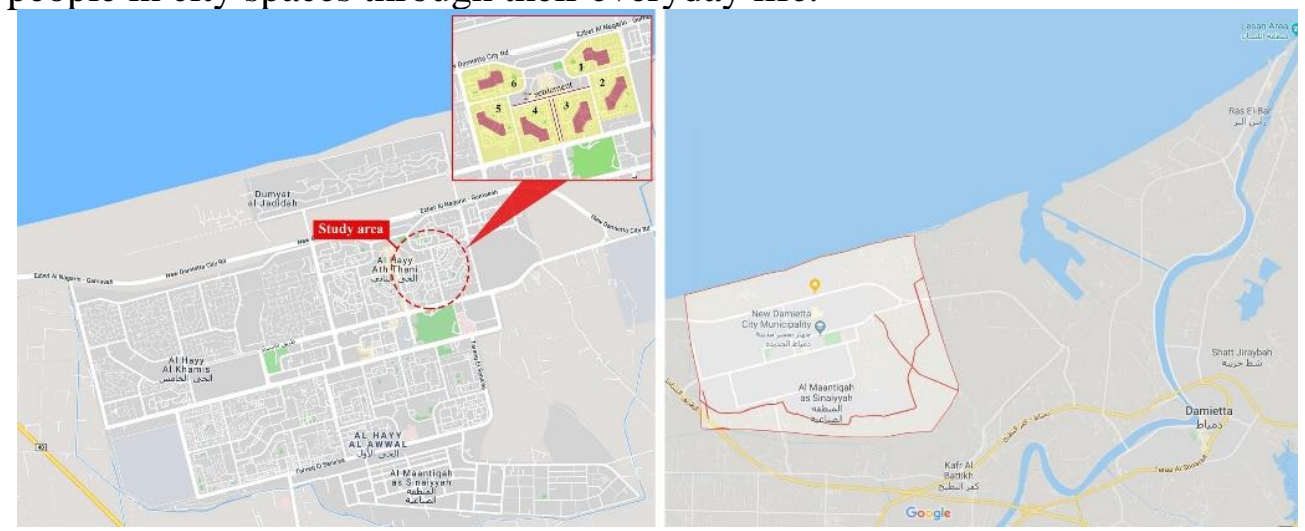

Figure (1) - New Damietta city map. Source: Google maps. 
Urbanity levels can be enhanced through making good places. Many urban planners argued in making good places, such as Cullen [10], Lynch [11], Alexander [12], and Jacobs [13]. Canter [14] combined elements of making good places from these perceptions to be activities, physical attributes, and conceptions. These elements were reshaped by Punter [15]. Then Montgomery (1998) reshaped these elements to be form, image, and activities figure (2). Urban form refers to the physical characteristics of cities, their size, shape, and structure [16]. Conzen [17] developed a method to study urban form, the main elements of this method are street network, building density, and land use diversity. In this research, we will study urban form through, the street network configuration by spaces syntax analysis, land use pattern, and physical features in the built environment.

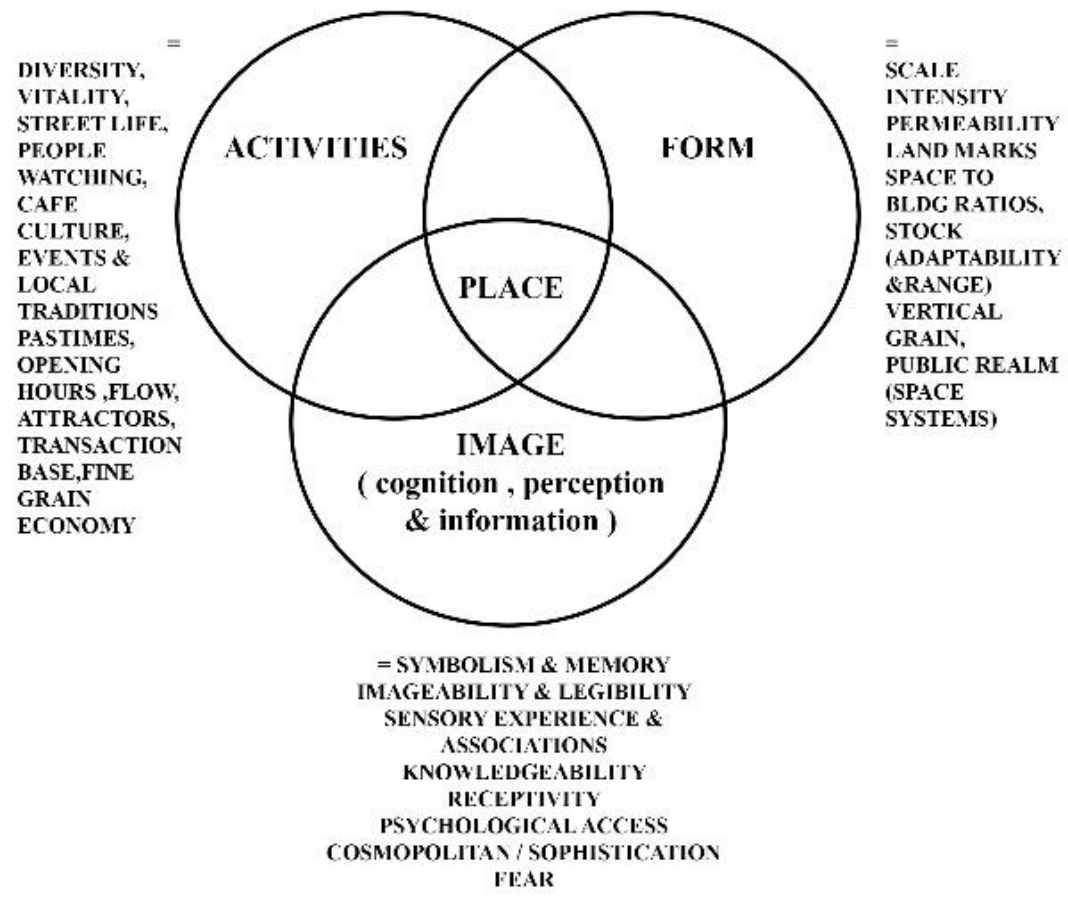

Figure (2) - Elements good place making (redrawn). Source: (Montgomery, 1998).

Image of the city according to Lynch [11] is how it is legible, navigable, and visually recognized. We measured the image of the city through intelligibility in space syntax analysis [18]. Intelligibility describes the image of the city from the configuration of its layout, it indicates how the city is easily navigable and legible. Gehl [19] classified activities into; necessary activities that people have to do under any conditions such as going to work, school, and shopping. Optional activities which people make based on their desires, in addition to physical environment 
conditions which may encourage them to make these activities. Social activities such as conversations, greetings, hearing or seeing other people which depend on the existence of other people in the urban space. Activities in urban spaces are the basis of urbanity and urban vitality [20]. Activities were studied through direct field observations which are important to embody and reflect the relationships between space and users [13]. In this research observations were conducted during summer as good weather encourages people to stay outdoors and engage in activities, in addition summer coincide with students' vacation so they will have time to make activities. In these observations, 6 points were positioned in the study area with different surroundings. Observations were conducted during a weekday and a weekend in the morning $(10: 00 \mathrm{am})$, late afternoon $(4: 00 \mathrm{pm})$, and evening $(8: 00 \mathrm{pm})$ to reveal different patterns of activities that occurred around each point during different periods of the day.

\subsection{Space syntax}

Space syntax was originated and developed at the Bartlett Unit for Architectural Studies, University College London [21-18]. It is a set of theories and techniques used to analyze and describe patterns of human behaviors in spaces at buildings and cities. It describes the spatial configurations of urban and architectural structures and their influences on patterns of behavior. Depth map is the software used to analyze spaces in cities and buildings according to space syntax principles. It was created by Alasdair Turner at University College London [22]. To conduct this study, we ran angular segment analysis for metric radii at global and local levels to investigate movement potentials for vehicles and pedestrians.

\section{Research Method}

In this research we evaluated urbanity levels in New Damietta city, then found the correspondence between space syntax analysis and direct field observations, to explore to what extent space syntax analysis can reflect and predict social and economic patterns, so it can be enrolled in the design and planning process to enhance urbanity levels in new cities. We evaluated urbanity through studying elements of making good places, urban form, urban image, and activities.

\section{Evaluation of urbanity in New Damietta city}

In this research, we studied urban form through space syntax, land use patterns, and physical features of the built environment. The Urban image was studied by 
intelligibility scatterplot through space syntax analysis. Activities were studied through conducting direct field observations in the study area. Figure (3) shows points surrounding which observation sessions were conducted.

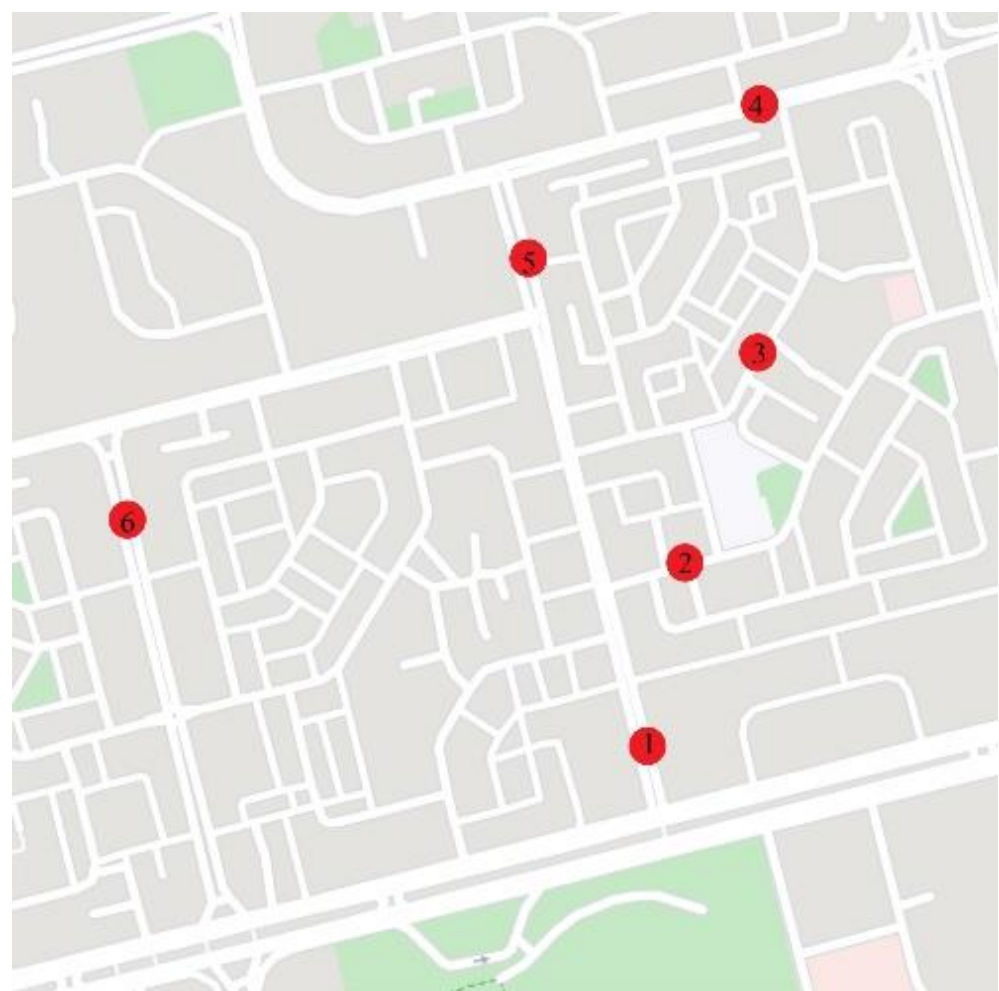

Figure (3) - Points of observations in New Damietta. Source: Google maps.

\subsection{Urban form in New Damietta city}

\subsubsection{Space syntax analysis}

Global and local Integration: Integration measures the closeness of elements to other elements in the system, it indicates the accessibility for the to-movement potentials [22]. From analysis figure (4) we can find that arterial and collector streets obtained the highest degrees, local streets inside the areas obtained lower degrees for global integration which investigates vehicular movement. For local integration, which investigates pedestrian movement all streets obtained low degrees.

\subsubsection{Land use pattern}

Around point 1 there was a mosque, public garden, and New Damietta station. Around point 2 there were residential and education buildings. For point 3 there 
was high land use mix; residential, educational, commercial, administrative, and healthcare. Around point 4 there were only residential uses, around point 5 there were residential, educational, and administrative uses in addition to commercial activities from street vendors. Point 6 had high land use mix, residential, commercial, administrative, and recreational as shown in figure (5).

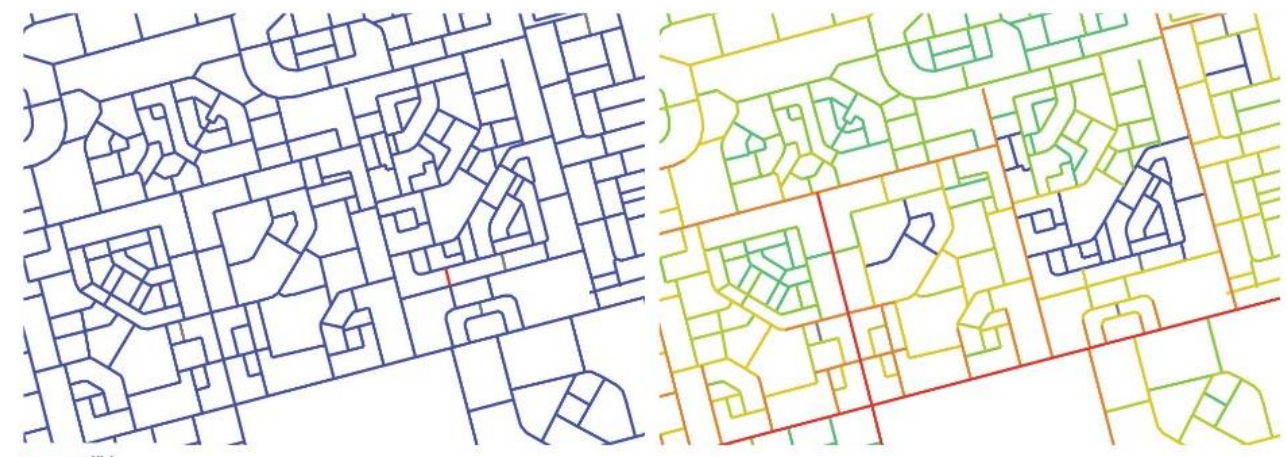

Figure (4) - Space syntax analyses, local integration R500 (left) and global integration Rn (right) in New Damietta city. Source: Authors through depth map software.

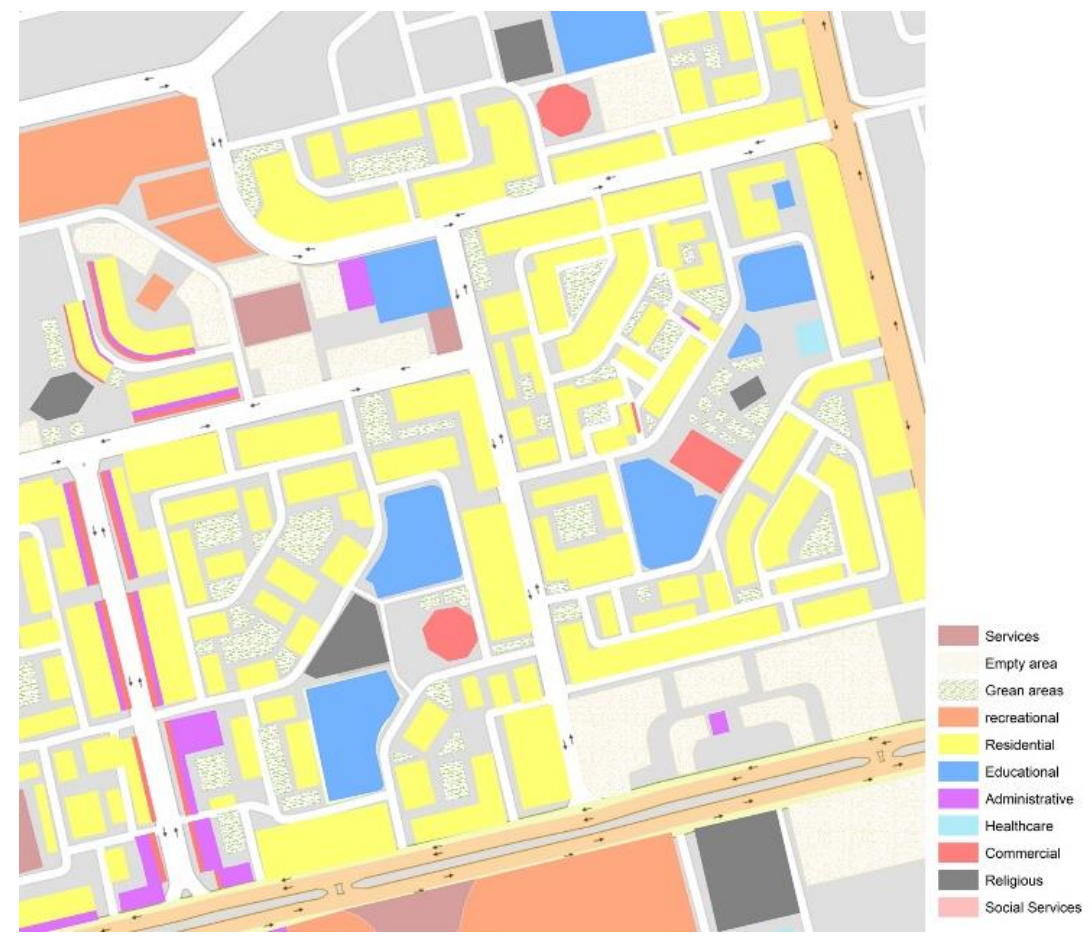

Figure (5) Land use distribution for New Damietta city. Source: Authors through GIS software. 


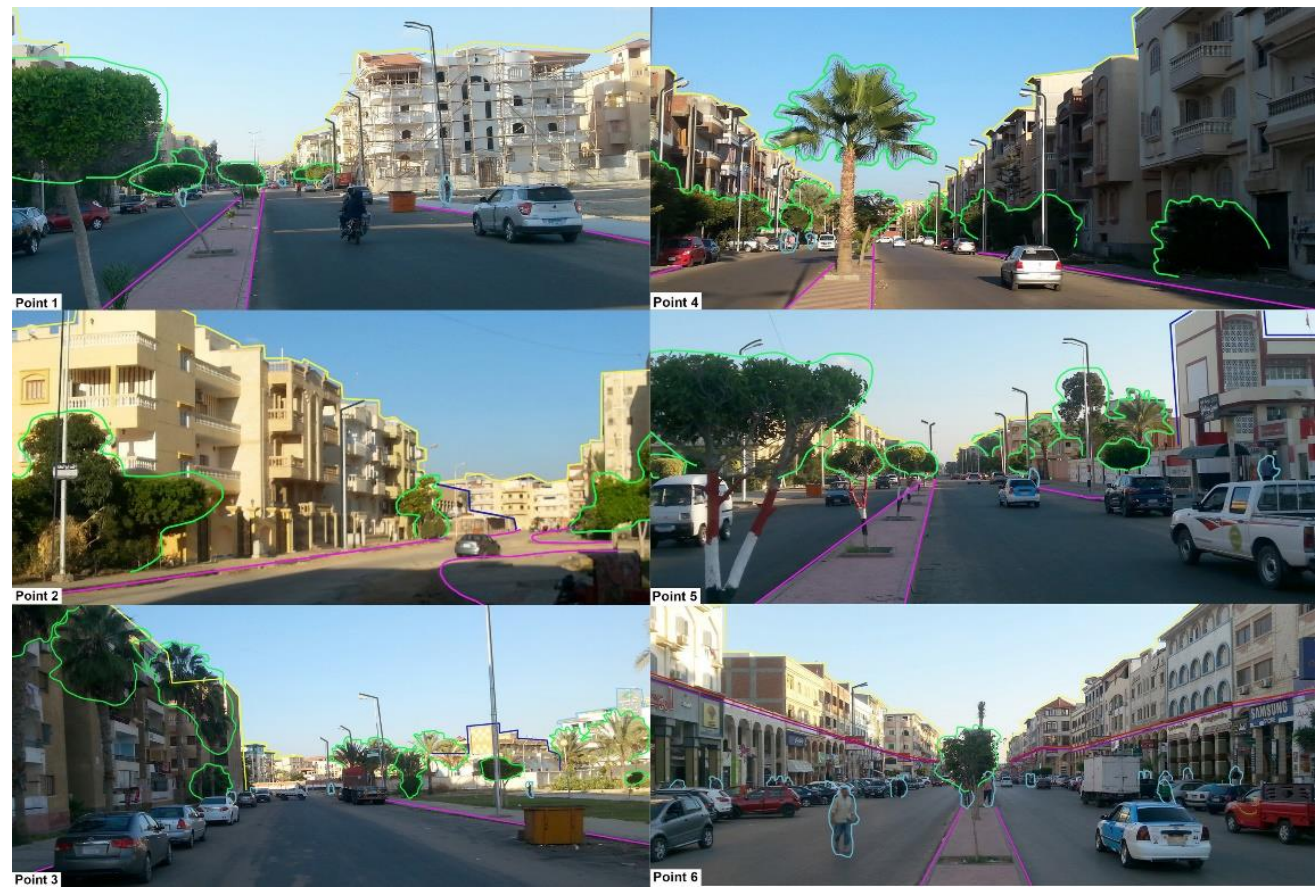

Figure (6) - Photos of observation points 4, $5 \& 6$. Source: Authors.

\subsection{Urban image in New Damietta city}

Image of the study area was studied through intelligibility scatterplot. It indicates how the city is legible from its layout. Intelligibility is the correlation between connectivity and global integration in space syntax analysis. It is a degree between 0 and 1 , if the points shape a line with a slope around $45^{\circ}$, it means high $\mathrm{R}^{2}$ and a high degree of intelligibility. If the points are diffused, the $\mathrm{R}^{2}$ is low and the intelligibility degree as well [18]. Figure (7) shows low $\mathrm{R}^{2}$ and therefore a low degree of intelligibility in the study area and the whole city. The city is not navigable easily, one can get confused about the place he wants as there are many areas like each other.

\subsection{Interactions and activities in the study area (social and economic)}

We studied social and economic activities in the study area surrounding the selected points. Activities occurred there were observed, documented, and mapped in GIS. A sample of the observation table is shown in figure (8). Point 1 overlooks a collector street, the vehicular movement there was relatively high, especially in the morning. Points 2 and 3 are located on local streets, the traffic flow there was low, especially in the evening. Points 4 and 5 lies in a collector street so the traffic there was higher than before. Point 6 lies in a collector street and had the highest 
traffic flow. In GIS, each point represents one person engaging in the space figure (9).

Observations on weekday morning figure (8) show that at point 1 there were not many people, it might due to the hot weather in the morning, the majority of activities were walking, some men were cycling, and this point is located near New Damietta station. Point 2 had a lower number of people, activities also were walking and cycling, many of the walking people were going shopping (were holding bags of vegetables and fruits). Point 3 had more people than the previous two points, this is due to the high land use mix in the area, there were people going shopping or going to the Social Insurance office. Around point 4 numbers of people were low as there were residential buildings only, and the traffic there in the collector street is relatively high. At point 5 there were educational, administrative, and residential uses in addition to commercial activities as there were some street vendors there. So, the numbers of people there are higher than before. Point 6 is located in an area with high land use mix, it lies in the most vital street in the city (El Saidi st.). This street is also a collector street and has a high flow of vehicular movement, but the speed is not so high, so it did not restrict pedestrian movement. So, the numbers of people there were much more than all observed points.

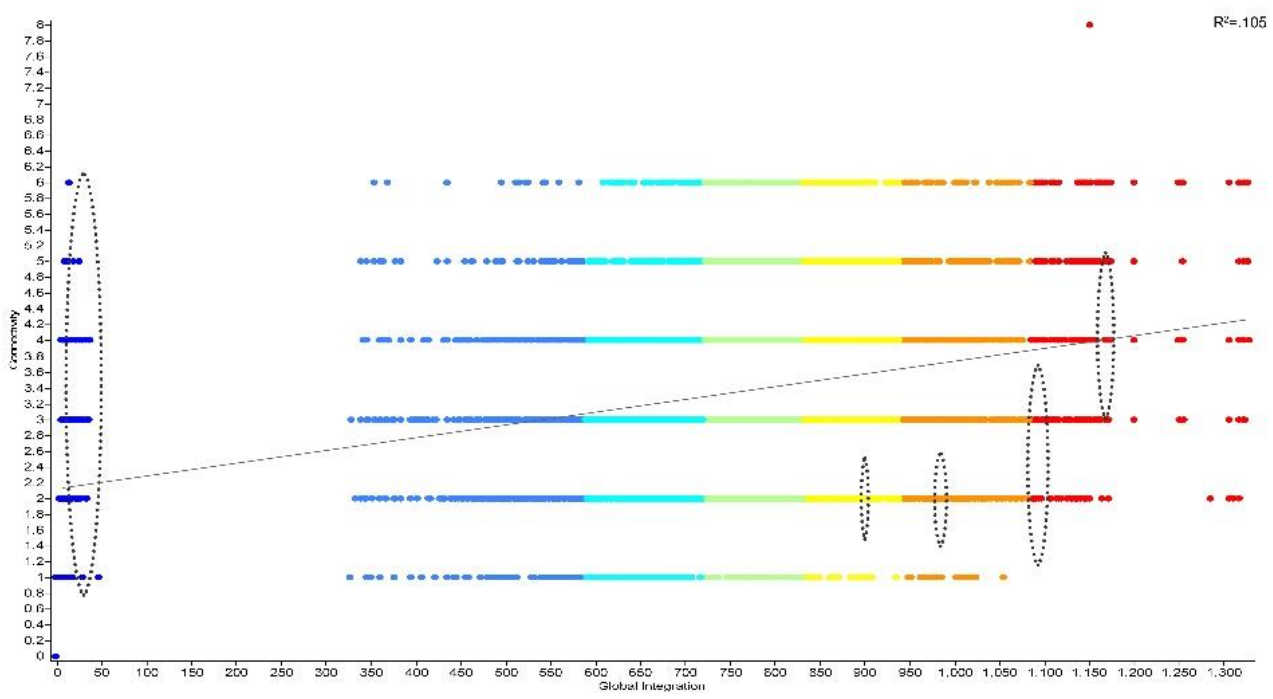

Figure (7) - Intelligibility scatterplot between connectivity and global integration in New Damietta. Source: Authors through depth map and GIS software 
Asmaa Eldiasty et al., space syntax as an evaluative and predictive tool to explore .......

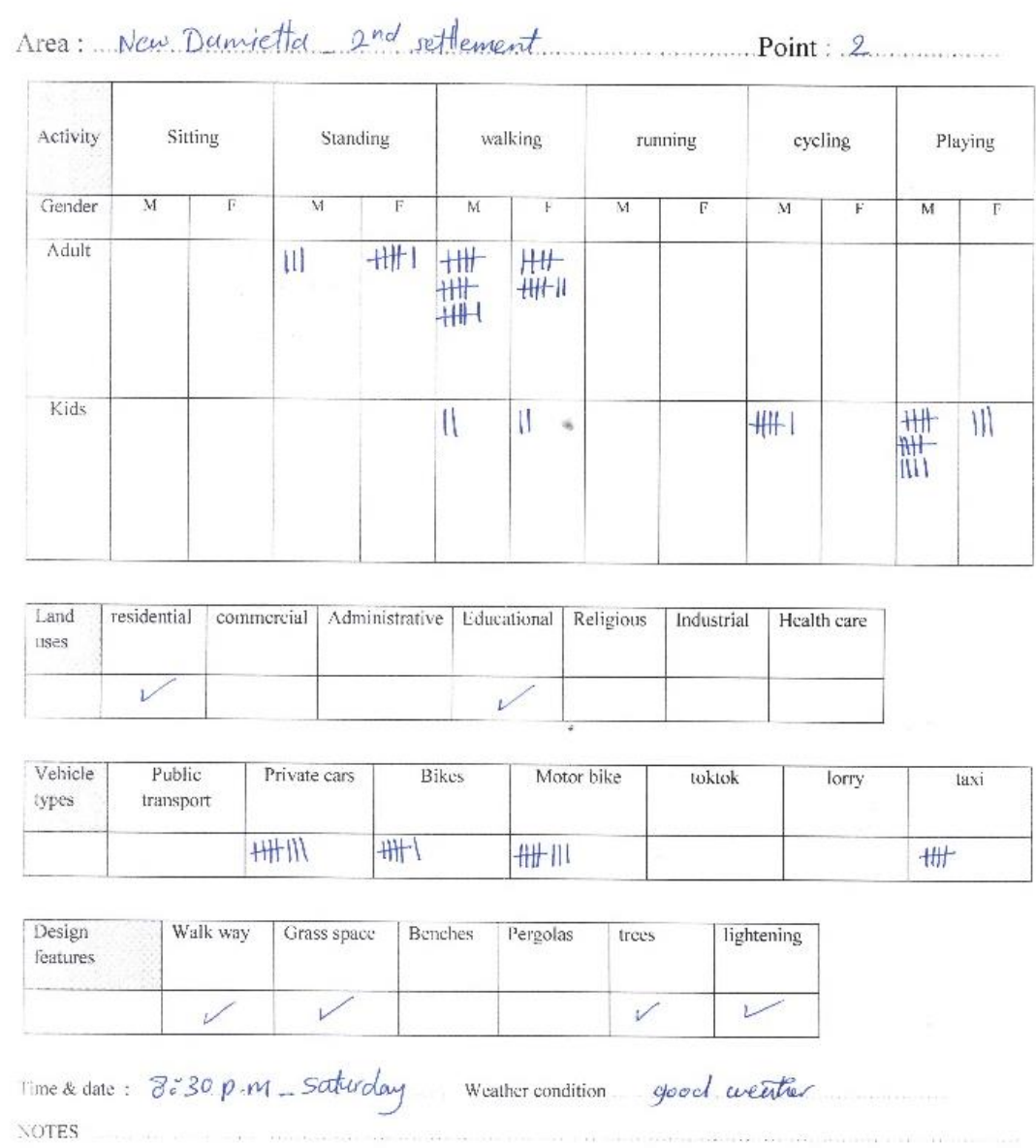

Figure (8) - Sample of the table used to document observations. Source: Authors

On weekday late afternoon, numbers of people at point 1 have decreased although many parts of the street were shaded. At point 2 numbers of people have increased, there were kids playing, walking, standing, or cycling. At point 3 numbers of people have also increased, we could see more kids than before playing, walking, or cycling. A street vendor collected some people around her. Numbers of people at points 4 and 5 have increased. Also, we can see that some people were sitting, walking, or standing, at point 5 there were some kids playing, some people were standing around a street vendor. At point 6 numbers of people have increased to more than double, most of them were shopping, going back from work or just hanging out.

Weekday evening observations showed that at point 1 numbers of people have increased, most activities occurred there were walking for both adults and kids. At point 2 the numbers of people have also increased, there were more people walking, standing, or talking, there were children playing and cycling. Lighting at point 2 was not as good as point 1 . At point 3 the numbers of people have 
decreased, especially kids, there were only two kids cycling may be because the area was not lightened well. At point 4 numbers of people have decreased to lower than the half, all of them were adults walking or sitting. The reason may be the low land use mix and bad lighting. At point 5 numbers of people have increased slightly, especially numbers of adults. The numbers of children have decreased may because the area was not lightened well, so it was not safe for parents to let children stay outdoors. At point 6 numbers of people have increased, many of them went there for shopping or to health clinics (many of them are open in the evening). Vehicular and pedestrian traffic in the evening are heavier than the morning and the late afternoon. Design features in all points are trees, green spaces, lighting, and pavements, we could find only one seat in the area surrounding point 5 .

At weekend observations activity patterns were different for all points. At morning observations numbers of people at all points have decreased because many employees were off.

At weekend late afternoon, numbers of people at points 1 and 2 have decreased. At point 3 numbers of people have increased especially numbers of kids, they were walking, playing, or cycling. At point 4 numbers of people have increased, especially numbers of adults, they were sitting, walking, or standing. The numbers of kids have also increased, they were playing or cycling. The numbers of people at point 5 have also increased. At point 6 the numbers of people have increased as people like to do shopping at weekends. The increase in numbers of people around many points was due to good weather during late afternoon hours and the weekend.

At weekend evening observations, numbers of people have increased in many points, but decreased in others. At point 1 numbers of people have increased to more than at morning and late afternoon. The numbers also have increased in point 2, also numbers of kids playing, or cycling have increased. At point 3 numbers of people have decreased especially kids despite the good weather. At point 4 numbers of people were much lower than before. At point 5 numbers of people have increased, many people were standing around vendors in the street. Point 6 obtained the highest number of people. 

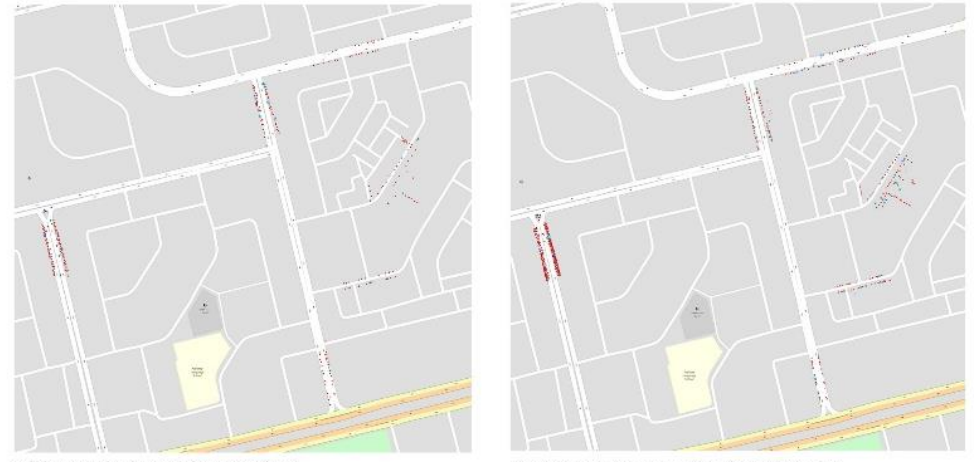

Activity mapping at weekday (morning)

Activity mapping at weekday ( late afternoon)

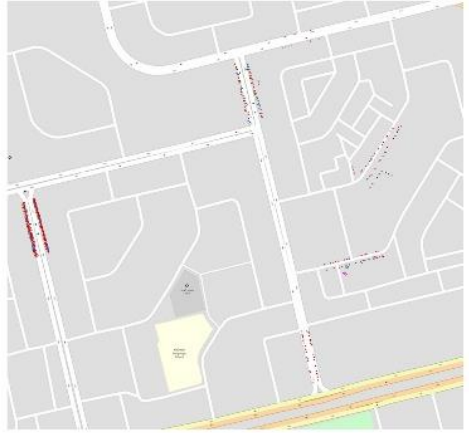

Activity mapping at weekday (evening )
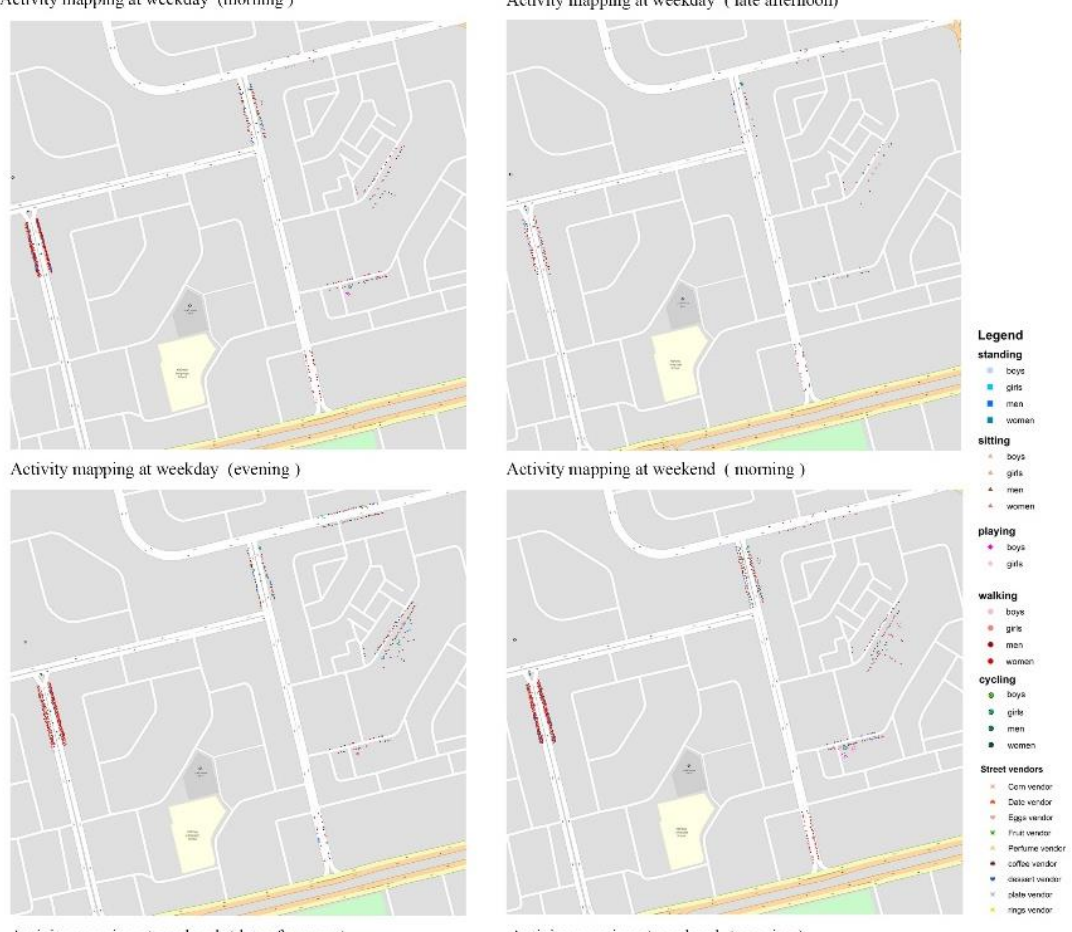

Activity mapping at weekend ( late afternoon )

Activity mapping at weekend ( evening)

Figure (9) - Activity maps for the study area. Source: Authors by GIS

\section{Findings}

Results show that vibrant street life can be found where there is a high degree of integration, high land use mix. The availability of physical design features may also encourage people to stay in urban spaces. We can arrange the points we observed according to their level of urbanity (numbers of people engaging in activities) or street life from high to low level according to results from observations and analyses table (1). 
Table (1) Arranging points of observations according to their levels of urbanity. Source: Authors.

\begin{tabular}{|c|c|c|c|c|c|c|c|c|c|c|c|c|}
\hline \multirow{2}{*}{\multicolumn{2}{|c|}{$\begin{array}{l}\text { Points of observations } \\
\text { arranged according to } \\
\text { their levels of urbanity }\end{array}$}} & \multicolumn{3}{|c|}{ Integration degrees } & \multicolumn{6}{|c|}{$\begin{array}{c}\text { Number of Land uses } \\
\text { types }\end{array}$} & \multicolumn{2}{|c|}{$\begin{array}{c}\text { Numbers of people } \\
\text { making different } \\
\text { activities during } \\
\text { observations }\end{array}$} \\
\hline & & high & mean & Low & 1 & 2 & 3 & 4 & 5 & 6 & During & During \\
\hline$\stackrel{0}{\stackrel{0}{\Xi}}$ & $\begin{array}{l}\text { High degree of } \\
\text { integration } \\
\text { High diversity of } \\
\text { land uses (5 } \\
\text { different land uses) }\end{array}$ & - & & & & & & & $\bullet$ & & 660 & 658 \\
\hline $\begin{array}{l}n \\
. \\
.0 \\
0\end{array}$ & $\begin{array}{l}\text { High degree of } \\
\text { integration } \\
\text { High diversity of } \\
\text { land uses (4 } \\
\text { different land uses) }\end{array}$ & - & & & & & & - & & & 191 & 186 \\
\hline$\stackrel{n}{\mathscr{n}}$ & $\begin{array}{l}\text { Low degree of } \\
\text { integration } \\
\text { High diversity of } \\
\text { land uses ( } 6 \\
\text { different land uses) }\end{array}$ & & & - & & & & & & - & 143 & 136 \\
\hline 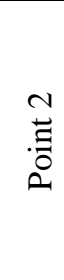 & $\begin{array}{l}\text { Low degree of } \\
\text { integration } \\
\text { Poor diversity of } \\
\text { land uses ( } 2 \\
\text { different land uses), } \\
\text { but the area is near a } \\
\text { commercial center }\end{array}$ & & & - & & - & & & & & 126 & 105 \\
\hline 苛 & $\begin{array}{l}\text { High degree of } \\
\text { integration } \\
\text { Poor diversity of } \\
\text { land uses } \\
\text { (residential only), } \\
\text { but there are a } \\
\text { mosque, public } \\
\text { garden, and New } \\
\text { Damietta station } \\
\text { near the area. }\end{array}$ & - & & & & & & - & & & 92 & 86 \\
\hline $\begin{array}{l}\stackrel{+}{\Xi} \\
.0 \\
.\end{array}$ & $\begin{array}{l}\text { Mean degree of } \\
\text { integration } \\
\text { Poor diversity of } \\
\text { land uses } \\
\text { (residential only) }\end{array}$ & & - & & $\bullet$ & & & & & & 91 & 83 \\
\hline
\end{tabular}

From table (1) we found that the street network configuration is the most powerful element in urbanity making, as it affects patterns of land use and then affects activities. As well integrated streets attract land uses such as commercial, 
administrative, or retail and low integrated streets attracts land uses such as residential [23]. Areas with a diversity of land uses but low integration degrees have low urbanity levels. The correlation between local and global integration indicates the configurational structure of the city, Hillier [23] mentioned that integrated centers (well connected) have a high correlation between local and global integration. But, in New Damietta city the correlation is low as the slope indicated in figure (10).

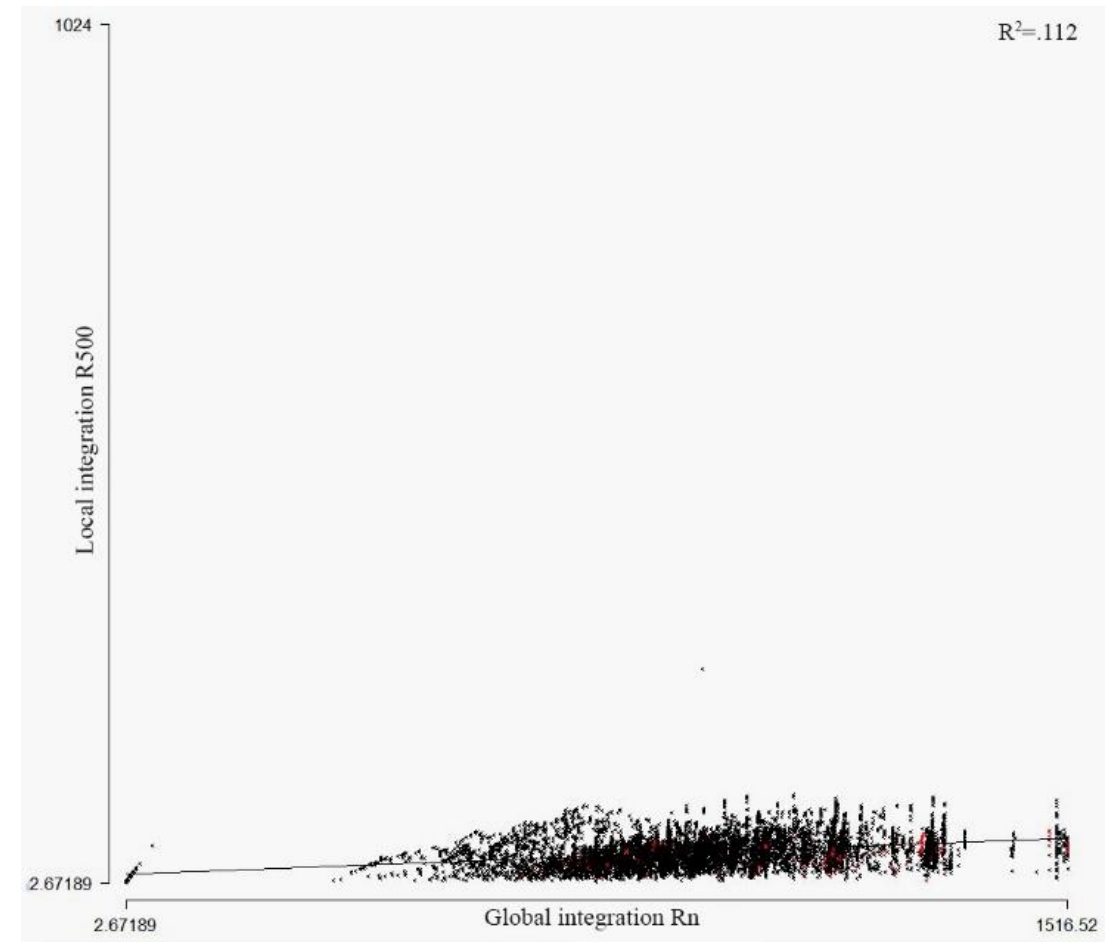

Figure (10) - Correlation between local and global integration in New Damietta city, each dot represents a street in the city. Source: Authors through depth map software

Results from space syntax analysis and distribution of land use showed high correspondence with observations. Streets that obtained high integration degrees with high land use mix have the most activities such as points 5 and 6. Streets that obtained low integration degrees and poor land use mix have few activities, such as point 2. Streets that have high integration degrees, but low diversity of land use have few activities such as points 1 and 4 . Streets that have low integration degrees and high land use mix have few activities such as point 3 . These results show that space syntax combined with land use pattern can predict areas with more activities and interactions in the city. 


\section{Conclusions}

In this inquiry, we investigated urbanity level in New Damietta city through applying quantitative and qualitative methods. The combination of space syntax analysis and direct field observations has uncovered many characteristics of urbanity inside the residential neighborhoods. Results show that the configuration of the street network plays an important role in enhancing urbanity in the city. It influences land use distribution, activity patterns, and movement flows in the city. The neighborhood unit model seems to fail in achieving flourishing street life inside the residential areas. The city structure seems like identical copies from each other which makes people get confused about the place they want as the results from intelligibility showed.

The problems in New Damietta can be stated in some points:

- Low street network integration specially at local level led to separated neighborhoods and separated local centers.

- The low degree of street network integration affected land use mix and created mono-functional areas.

- Low degree of urbanity in many areas.

The study highlights the importance of space syntax analysis in urban planning and that it would help enhance urbanity and overcome future problems in new cities.

Through this study we can recommend some solutions to enhance urbanity:

1) New connections can be made in and between neighborhoods and settlements to improve street network integration in the city (this can be applied on settlements and areas under construction).

2) Design features in spaces should be provided to encourage people to stay outdoors.

3) Redistribution of local centers around the city to be near to all dwellers.

\section{References}

[1] New Urban Communities Authority. (2019, May 10). know cities, New Damietta, website: http://www.newcities.gov.eg/english/New Communities/Damietta/default.aspx

[2] Perry, C.A. (1929) "The Neighborhood Unit: A scheme of arrangement for the Family Life Community." In A Regional Plan for New York and Its Environs, Volume vii. New York.

[3] Hillier, B. (2006), The golden age for cities? How we design cities is how we understand them. In: Urban Design 100th Issue, p.16-19.

[4] Karimi, K. \& Vaughan, LS. (2014). An evidence-based approach to designing new cities: The English New Towns revisited

[5] Banerjee, T.K., \& Baer, W.C. (1984). Beyond the neighborhood unit: residential environments and public policy. Springer Science+Business Media, LLC.

[6] The built environment observatory. (2018, October 15). Myths and Facts of Urban Planning in Egypt, website: http://marsadomran.info/en/policy_analysis/2016/11/501/ 
Asmaa Eldiasty et al., space syntax as an evaluative and predictive tool to explore ......

[7] Ye, Y. (2012). New town modeling Reviewing Dutch new towns via quantitative methods to provide appropriate tools and strategy for accelerating Chinese new town development, using songjiang new town as the TEST case, MSc thesis, Delft University of Technology.

[8] Zhou, J. (2012). Urban Vitality in Dutch and Chinese New Towns. A comparative study between Almere and Tongzhou, MSc thesis, Urbanism department, Faculty of Architecture, TU Delft.

[9] Montgomery, J. (1998). Making a City: Urbanity, Vitality and Urban Design. Journal of Urban Design, 3, 93-116. http://dx.doi.org/10.1080/13574809808724418

[10] Cullen, G. (1961). Townscape (London, Architectural Press).

[11] Lynch, K. (1960). The Image of the City (Cambridge, MA, MIT Press).

[12] Alexander, C. (1979). A Timeless Way of Building (New York, Oxford University Press).

[13] Jacobs, J. (1961). The Death and Life of Great American Cities (London, Vintage Books).

[14] Canter, D. (1977). The Psychology of Place (London, Architectural Press).

[15] Punter, J. (1991). Participation in the design of urban space, Landscape Design, 200, pp. 2427.

[16] Anderson, W. P., Kanargoglou, P. S. and Miller, E. (1996). Urban Form, Energy, and the Environment: A Review of Issues, Evidence and Policy. Urban Studies, 33, pp. 17-35

[17] Conzen, M. R. G. (1960). Alnwick, Northumberland: A study in town-plan analysise. In: Transactions and Papers (Institute of British Geographers), Vol. 27, p.iii-122.

[18] Hillier, B. (1996). Space is the Machine: A configurational theory of architecture, Cambridge: Cambridge University Press.

[19] Gehl, J. (2011). Life between Buildings: Using Public Space. Washington DC: Island Press.

[20] Gehl, J. (1989). A changing street life in a changing society, Places (Fall), pp. 8-17.

[21] Hillier, B. and Hanson, J. (1984). The social logic of space, Cambridge: Cambridge University Press.

[22] Al_Sayed, K., Turner, A., Hillier, B., Iida, S., Penn, A., (2014) (4th Edition), "Space Syntax Methodology", Bartlett School of Architecture, UCL, London.

[23] Hillier, B. (1999). Centrality as a process: accounting for attraction inequalities in deformed grids. Urban Design International. 4 (3-4), p. 107-127. 


\section{تقتيات التحليل الفراغي كأداة لتقييم وتوقع معدلات الحيوية الحضرية في مدينة دمياط الجديدة}

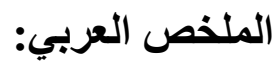

تبدو العديد من المجاورات السكنية في مدينة دمياط الجديدة كأماكن مملة ورتيبة حيث انخفاض معدلات الحيوية الحضرية في الثوارع والفر اغات. يعزو بعض الباحثين المستويات المنخفضة من الحيوية الحضرية في المدن الجديدة إلى مناهج التخطيط الحضري المتبعة (المجاورة السكنية). في هذا البحث، تم استخدام (space syntax) كأداة رئيسية لدراسة الحيوية الحضرية في مدينة دمياط الجديدة بالإضافة إلى طرق أخرى مثل الملاحظات الميدانية المباشرة التي لاحظنا من خلالها استخدامات الأراضي وأنماط الأنشطة الاجتماعية والاقتصادية في منطقة الدراسة. تم رسم خرائط استخدام الأراضي وأنماط الأنشطة المرصودة في نظام المعلومات الجغرافية (GIS) .توضح هذه الدراسة أهمية (space) Syntax analysis) للتنبؤ بالحيوية الحضرية أثناء تخطبط المدن الجديدة. 